\title{
WORLDVIEW, SOCIAL CONSOLIDATION, SCIENCE: DIALECTIC RELATIONSHIP
}

\author{
๑ 2019 KYZYM M. O., DORONINA M. S.
}

UDC 101.8

JEL Classification: A1

Kyzym M. O., Doronina M. S.

Worldview, Social Consolidation, Science: Dialectic Relationship

In Ukraine, the problem of social consolidation, the current state of which does not allow for a meaningful forecasting of its future, is getting more urgent. Many publications propose recommendations for solving this problem through a permanent diagnosing of mechanisms for the formation and development of worldview resources. The $\rightarrow$-world around a person is continuously and abruptly changing and requires developing scientifically based mechanisms for conscious adapting of a person to it. The aim of the article is generalizing the prerequisites for the creation of theoretical and methodological support for harmonizing the development of a worldview, social consolidation and science in Ukraine. Worldview creates for a person a general view of the outside world he/she is guided by when making important decisions and committing acts of social significance. Studying worldview allows determining what social patterns should be built in Ukraine, how to organize the constructive discussion of the way of solving the current problems by people with different worldviews; will help adapt the system of dialectical principles that are traditionally used by scientists in Ukraine to studying worldview. The article presents the definitions of the basic categories of the topic under study, the attention being focused on the dependence of the worldview orientations and the model of behavior of a person, first of all, on his/her financial standing. Solving complex tasks set by the internal development of our society and the international situation puts forward a pressing issue of forming a systematized scientific worldview. Tackling problems of worldview of a society can be facilitated by revision of the concepts of building its scientific and educational spheres. Worldview management should be oriented not towards standard functions and principles of management but towards the formation of conditions for enhancing internal conscious sources of people's desire to carry out their own unique ideas in practice. The processes of consolidation and solidarity are implemented both in society as a whole and its scientific sphere, in particular. They are manifested in their full in schools of thought.

Keywords: worldview, consolidation and solidarity among the members of society, factors influencing the worldview formation and development, educational and scientific sphere of society, schools of thought.

DOl: https://doi.org/10.32983/2222-0712-2019-4-156-162

Bibl.: 27.

Kyzym Mykola O. - Doctor of Sciences (Economics), Professor, Corresponding Member of NAS of Ukraine, Director of the Research Centre of Industrial Problems of Development of NAS of Ukraine (2 floor 1a Inzhenernyi Ln., Kharkiv, 61166, Ukraine)

E-mail: ndc_ipr@ukr.net

ORCID: http://orcid.org/0000-0001-8948-2656

Researcher ID: http://www.researcherid.com/Y-5422-2019

SPIN: http://elibrary.ru/7616-1550

Doronina Maya S. - Doctor of Sciences (Economics), Professor, Senior Research Fellow of the Research Centre of Industrial Problems of Development of NAS of Ukraine (2 floor 1a Inzhenernyi Ln., Kharkiv, 61166, Ukraine)

E-mail:doroninamas@gmail.com

ORCID: https://orcid.org/0000-0001-8074-375X

Кизим М. О., Дороніна М. С. Світогляд, консолідація суспільства, наука: діалектичний взаємозв'язок

В Україні набуває актуальності проблема консолідації суспільства, нинішній станякоїнедозволяєосмисленопрогнозуватийогомайбутнє. у багатьох публікаціях пропонуються рекомендації розв'язку чієї проблеми за рахунок перманентної діагностики механізмів формування й розвитку світоглядних ресурсів. Оточуючий людину світ постійно непередбачувано змінюється і потребує розробки науково обгрунтованих механізмів усвідомленого пристосування до нього людини за рахунок розвитку ії світогляду. Метою цієї статті є узагальнення передумов створення теоретико-методологічного забезпечення гармонізації розвитку світогляду, консолідації суспільства й вітчизняної науки. Світогляд створює для людини загальну картину навколишнього світу, якою вона керується, ухвалюючи життєво важливірішення таздійснюючи соціальнозначущівчинки. Дослідження світогляду дозволить визначити, яку модель суспільства потрібно й можна побудувати в Україні, які створити технології гармонізації
Кизим Н. А., Доронина М. С. Мировоззрение, консолидация общества, наука: диалектическая взаимосвязь

В Украине приобретает актуальность проблема консолидации общества, нынешнее состояние которой не позволяет осмысленно прогнозировать его будущее. Во многих публикациях предлагаются рекомендации решения этой проблемы за счет перманентной диагностики механизмов формирования и развития мировоззренческих ресурсов. Окружающий человека мир постоянно непредвиденно меняется и нуждается в разработке научно обоснованных механизмов осознанного приспособления к нему человека за счет развития его мировоззрения. Целью данной статьи является обобщение предпосылок создания теоретико-методологического обеспечения гармонизации развития мировоззрения, консолидации общества и отечественной науки. Мировоззрение создает для человека общую картину окружающего мира, которой он руководствуется, принимая жизненно важные решения и совершая социально значимые поступки. Исследование мировоззрения позволит определить, какую модель общества нужно и можно 
механізмів його консолідації й солідарності, як забезпечити конструктивне обговорення способів вирішення насущних проблем представниками різних світоглядів; допоможе адаптувати традиційну для вітчизняної науки систему діалектичних принципів до дослідження світогляду. У статті наведено визначення центральних категорій статті, акцентовано увагу на залежності світоглядних орієнтацій і моделі поведінки людину передусім від ії матеріального становища. Вирішення складних завдань, поставлених внутрішнім розвитком нашого суспільства й умовами міжнародної ситуації, висуває з усією гостротою завдання формування систематизованого наукового світогляду. Розв'язанню проблем світогляду суспільства здатне сприяти відновлення концепцій побудови його наукової та освітньої сфер. У керуванні світоглядом необхідно орієнтуватися не на стандартні функції й принципи менеджменту, а на формування умов активізації внутрішніх свідомих джерел бажання людей реалізувати власні унікальні ідеї. Процеси консолідації і солідарності реалізуються як у суспільстві, так і в науковій сфері суспільства. 3 усією виразністю вони проявляються в наукових школах.

Ключові слова: світогляд, консолідація т солідарність суспільства, фактори формування та розвитку світогляду, освітня й наукова сфери суспільства, наукові школи.

Бібл.: 27.

Кизим Микола Олександрович - доктор економічних наук, професор, член-кореспондент НАН України, директор Науково-дослідного чентру індустріальних проблем розвитку НАН України (пров. Інженерний, 1a, 2 пов., Харків, 61166, Україна)

E-mail: ndc_ipr@ukr.net

ORCID: http://orcid.org/0000-0001-8948-2656

Researcher ID: http://www.researcherid.com/Y-5422-2019

SPIN: http://elibrary.ru/7616-1550

Дороніна Майя Степанівна - доктор економічних наук, професор, старший науковий співробітник Науково-дослідного центру індустріальних проблем розвитку НАН України (пров. Інженерний, 1a, 2 пов., Харків, 61166, Україна)

E-mail:doroninamas@gmail.com

ORCID: https://orcid.org/0000-0001-8074-375X построить в Украине, какие создать технологии гармонизации механизмов его консолидации и солидарности, как обеспечить конструктивное обсуждение способов решения насущных проблем представителями разных мировоззрений; поможет адаптировать традиционную для отечественной науки систему диалектических принципов к исследованию мировоззрения. В статье представлены определения центральных категорий статьи, акцентировано внимание на зависимости мировоззренческих ориентаций и модели поведения человека в первую очередь от его материального положения. Решение сложных задач, поставленных внутренним развитием нашего общества и условиями международной ситуации, выдвигает со всей остротой задачу формирования систематизированного научного мировоззрения. Решению проблем мировоззрения общества способно содействовать обновление концепций построения его научной и образовательной сфер. В управлении мировоззрением необходимо ориентироваться не на стандартные функции и принципы менеджмента, а на формирование условий активизации внутренних сознательных источников желания людей реализовать собственные уникальные идеи. Процессы консолидации и солидарности реализуются как в обществе, так и в научной сфере общества. Со всей отчетливостью они проявляются в научных школах.

Ключевые слова: мировоззрение, консолидация и солидарность общества, факторы формирования и развития мировоззрения, образовательная и научная сферы общества, научные школы.

Библ.: 27.

Кизим Николай Александрович - доктор экономических наук, профессор, член-корреспондент НАН Украины, директор Научноисследовательского чентра индустриальных проблем развития НАН Украины (пер. Инженерный, 1a, 2 эт., Харьков, 61166, Украина)

E-mail:ndc_ipr@ukr.net

ORCID: http://orcid.org/0000-0001-8948-2656

Researcher ID: http://www.researcherid.com/Y-5422-2019

SPIN: http://elibrary.ru/7616-1550

Доронина Майя Степановна - доктор экономических наук, професссор, старший научный сотрудник Научно-исследовательского чентра индустриальных проблем развития НАН Украины (пер. Инженерный, 1a, 2 эт., Харьков, 61166, Украина)

E-mail: doroninamas@gmail.com

ORCID: https://orcid.org/0000-0001-8074-375X
Introduction. After the disintegration of the USSR, Ukraine faced the task of tackling the issue of social consolidation, its people's rallying around new common values. These processes can help confront challenges associated with the life of the newly founded state and threats to it, solve the problems of harmonizing the joint existence of dissimilar but interconnected languages, cultures. The development of any organization and society as a whole is determined by the consciousness of an individual, his/her worldview. In Ukraine, the problem of worldview is becoming increasingly urgent due to the impossibility of a meaningful forecasting of the future without solving it.

Though the problem has been highlighted in a vast number of publications, it remains relevant today. It is due to the fact that the world is continuously changing and requires developing mechanisms for conscious adaptation of a person to it through developing his/her worldview. Ukraine is still facing the problem of deciding on what worldview values should be developed under current conditions. In this regard, it is appropriate to aim at developing and supporting the mechanisms of: a) social solidarity; b) social consolidation; c) their harmonious combination.

Analysis of recent researches and publications. The source material for the article is taken from publications of a number of scientists, namely: V. Vernadsky [7], L. Zelenov, A. Vladimirov [12], V. Shreiber [26], and others. The paper considers and summarizes the ideas expressed in the works of A. Aseev [2], V. Volovich [8], A. Okara [19], who show concern with problems related to the practice of transformation of society caused by the lack of scientifically based objectives. To develop the methodological support for solving the problem, the publications of V. Andrushchenko [1], V. Zhilin [10] are used. The content of the problems of social consolidation and reproduction of society in the context of the increased complexity and risk-taking of the modern world, which are reflected in the materials of scientific seminars of conferences $[14 ; 18 ; 20]$, is analyzed.

The aim of the article is generalizing the prerequisites for the creation of theoretical and methodological support for harmonizing the development of a worldview, social consolidation and science in Ukraine. 
As for the relationship between science and worldview, works of modern researchers reflect both a generalization of this problem and recommendations for its solution. A. Zelenkov, Head of the Department of Philosophy and Methodology of Science at the Belarusian State University, warns of the danger of ignoring worldview problems by science in our time: "The transitional state of society usually causes a deep shock to conventional forms of life activities. It is experienced by the mass consciousness as the onset of social chaos, as the collapse of established connections and relationships and is accompanied by a sense of abandonment, hopelessness, anxiety and fear. This is the time of lost values and unacquired meaning" [11].

As the Nobel Peace Prize winner (1952) Albert Schweitzer once rightly noted, "...for society as well as for an individual, life without a worldview is a pathological alteration of a higher sense of orientation" [25]. The success of each state, nation is determined by factors among which worldview plays an important role. The history of mankind gives many examples when communities that are united by a worldview and whose activities are directed by the worldview itself are much more effective.

K. Zuev and Ye. Krotkov, considering the correlation and interaction of worldview, philosophy and science, note: "The need for worldview - comprehension of basically undefined unambiguously ultimate foundations of the existence of the World around us and the enduring meaning of our transient life in it - will never be gone" [13]. Worldview creates for a person a general idea of the world around him/her, which he/she is guided by when making vital decisions and taking any socially significant actions.

We should admit that A. Vatulin is right in saying: "The struggle for the future in the modern world is a struggle not only for gold and oil but, first of all - for people's minds and ways to control them. And the main weapon here is not super-lasers on satellites but knowledge of the mechanisms of ideological processes and the ability to manage them. The state of affairs in this area should be of primary concern for us" [6].

The study of worldview is of great practical importance for Ukraine. Firstly, it will help determine what social pattern is needed and can be built in the country. Secondly, it will allow creating techniques for discussing ways to solve pressing problems by people with different worldviews. Thirdly, it will contribute to the development of educational techniques for forming a personality (a socially responsible citizen). Moreover, it will help adapt the system of dialectical principles that are traditionally used by scientists in Ukraine to studying worldview.

Attempts to formulate a unified concept for studying worldview are being carried out, but their results cannot be considered successful so far. In 2018, the multi-authored monograph "Worldview paradigm in philosophy: the basic foundations of ontoepistemology" was published [16]. Chapter 11 of the monograph is entitled "The matrix of the general theory of worldview" (L. Zelenov, A. Vladimirov). However, the matrix is not specified in it. In Chapter 15, "The paradigm and essence of a worldview", the author (V. Petrov) presents many types of worldviews characterizing their paradigms but does not give his vision of the content and essence of the "paradigm" construct. Therefore, it is difficult to define situations in which the proposed paradigms will work.

In this regard, it is advisable to provide an interpretation of the central concepts of this article: worldview, consolidation, science.

In philosophical literature, worldview is considered as a system of principles, views, values, ideals and beliefs that determine people's attitude to reality, general understanding of the world, life positions, and programs of their activities.

K. Zuev and Ye. Krotkov warn: "Today, humanity has already experienced the bitterness of worldview intolerance; racial, national, social egoism. It was confronted with the need to solve pressing environmental problems, prevent or overcome the consequences of natural disasters; came close to the clarification (philosophical understanding) of the coordinates of the single axiological space of the international community, principles of its global life identity, "code of humanity" [13].

In a multi-authored monograph (2010) dealing with the value orientations of institutionalizing economic development, Ukrainian scientists made the conclusion: "Philosophy, within the framework of which a general theory of worldview is developed, defines the concept of worldview as an ideal spiritual formation, which is a system of knowledge that allows a person to position him/herself in the outside world, orient him/herself in it as well as consciously evaluate, organize and carry out his/her own activities both individually and as part of a particular type of social aggregates" [24]. O. Bratuta, one of the authors of this monograph, focuses on the problem of the methodological crisis of economic theory and the prospects for overcoming it through studying processes of worldview formation. Ultimately, the author concludes that the concept of worldview is not widely represented in the categorical apparatus of economic theory. Its use by scientists has a sporadic character, is due to stylistic needs and has no informative value. According to the author, the mentioned concept does not fit into the modern paradigm of economic theory and is too ambiguous for it [24]. Thus, there is a need to develop a worldview in the field of economic science and practice.

With consideration for this, attention should be paid to recommendations of Ye. Bolshakov and Ye. Fedotov, who believe that overcoming the cultural and civilizational crisis experienced by modern mankind requires a comprehensive optimization of efforts of the international scientific community in developing worldview theory and methods for creating a holistic worldview in young, middle and older generations of people [4]. One of the reasons for the crisis state of society is, according to the authors, a low level of worldview literacy and general scientific education.

Regarding the concept "consolidation", it is advisable to pay attention to the materials of two scientific conferences organized by Irkutsk State University in 2014 and 2016. The complexity of working with the process of social consolidation is obvious, taking into account the complete duplication of the dimensions considered by the two conferences that were held with an interval of two years and brought together experts in human sciences.

The dimensions covered included:

1. Theoretical and methodological framework for studying social consolidation.

2. Social solidarity and social exclusion.

3. Symbolic resources for social consolidation of Russia.

4. Social stereotypes (ethnic, racial, class, gender) in the aspect of consolidation and disintegration.

5. Personal and social identifications as a resource for consolidation.

6. Social and communicative resources for social consolidation of Russia.

7. Factors related to foreign policy and prospects for consolidation among the members of modern Russian society. 
8. Social meaning of activities as a factor influencing social consolidation.

9. Educational resources for social consolidation.

10. Social opposition and its role in social consolidation.

11. Intergenerational continuity and sociocultural unity of society.

12. Transformation of language in the context of sociocultural unity.

13. Civilization resources for social consolidation of Russia.

14. Sociopsychological well-being of the population and the problem of social integration.

15. Ideological resources for consolidation among the members of modern Russian society.

And what is important - both conferences presented in the list of topics to be discussed the problem "Worldview of individual social groups in the integration aspect".

The situation with the concept "solidarity", which is used in studies of mechanisms for rallying various social communities, is not simpler than that with "consolidation". Sometimes this phenomenon is idealized, represented as the only mechanism for harmonizing relationships among people. A. Gofman expresses a different opinion in his comments to the article of a famous scientist H. Baudrillart "Solidarity, when it is alone, leads right to tyranny", published as early as 1854: "Modern history also fully confirms the fairly long-established truth that a single and indivisible solidarity can form the basis for various forms of despotism, suppression of personal and civil liberties... It should be emphasized once again: genuine solidarity cannot be directly derived from solidarity as a norm and duty. Forcing individuals to be in solidarity is as impossible as forcing them to be free. Therefore, the idea of solidarity in itself, not based on real mutual benefit, mutual interest, justice and individual freedom, is impossible, it has nothing to do with forced and imposed unity" [9].

Unfortunately, not all program documents concerning farreaching social reforms in Ukraine have a section on diagnosing and transforming the worldview of the population. For example, in this regard, in the Preface of Ukraine 2030: the Doctrine of Sustainable Development (2017), the authors make an explanation: "The research team is aware of the fact that in making the first attempt to generate new worldview values and new approaches to solving the most urgent tasks of the Ukrainian State it is impossible to raise all questions and provide comprehensive answers to them" [22]. And, practically, this Doctrine does not contain program activities for diagnosing the current worldview and forming a new one.

As already noted, clarifying the interpretation of the concept "worldview" creates prerequisites for the formation of a mechanism of consolidation and solidarity among certain communities. V. Ilin and A. Mashentsev, in their textbook on philosophy, give the following definition: "A worldview includes the person's understanding of the world, the place of the person in the world, the relationship between the person and the world, the sense of the person's life (the purpose of his/her life). Since the person lives in society, his/her worldview includes awareness of his/her social interests, social ideals, life values" [15].

L. Yarmol performed a comparative analysis of 27 definitions of this concept and proposed her own interpretation: "A person's worldview is a system of a number of components, "elements" of the person's consciousness (ideas, knowledge, attitudes, beliefs, faith, etc.) that make up the spiritual practical formation and pro- vide insight into the place the person occupies in the world, his/her attitude to the world and to him/herself [27].

The worldview of a person is closely connected with the internal mental processes of human conscience. The analysis of the main psychological approaches to its determination showed that a worldview is an activity on implementing external and internal social orientation. The internal way of orientation is the use of reflection for subordination of motives and activities; hierarchization of values, beliefs; formation of a personal meaning for assimilated social norms and values. The external way of orientation implies building a model of interaction with the outside world, with other people as well as choosing a behavior model. It is an alteration of the "higher sense of orientation" that can partly explain the complex of negative processes occurring in modern society: a decrease in the level of spiritual culture and its role in human life; the dominance of the philosophy of consumption; the instability in the moral attitudes of the young generation, their susceptibility to negative influences, loss of ideals and, as a result, the growth of drug addiction, alcoholism, aggression, crime, suicide.

In our time, the factor that influences the formation of a person's worldview is his/her financial standing. A person's ideological orientations and patterns of behavior change depending on the amount of material wealth he/she possesses.

To study worldview, one must have an idea of its types. Worldview studies use many of its classifications. For example, many scholars single out three types of worldview: everyday, religious and scientific one, each of which has its specific features. The structure of the worldview self-determination of a person (as a process and result) includes the following components: need and goal focused, knowledge, cognitive, emotional-volitional, activity, reflection and value focused, and effectiveness. Some scholars associate a worldview with the work of a person in a certain social sphere and distinguish political, legal, managerial, economic worldview, etc.

Despite qualitative differences among the types of worldview, it can be argued that any of them seeks to answer three basic questions: what is the world in which a person lives and acts; what should he/she live for; how he/she ought to live.

Solving the complex tasks set by the internal development of our society and the international situation puts forward the pressing issue of forming a systematized scientific worldview. However, it is necessary to take into account that this worldview should not be strictly distanced from the nonscientific and religious ones. V. Vernadsky warned: "Some parts of even the modern scientific worldview were not achieved due to scientific search or scientific thought - they entered science from outside: from religious ideas, from philosophy, from public life, from art. But they stayed in it only because they stood the test of the scientific method [7].

From the point of view of B. Stepin, the scientific worldview as well as the ideals and normative structures of science, in the period of their formation and subsequent transformation, require a peculiar connection with the prevailing worldview of a particular historical era, with the values of its culture [21]. The researcher believes that scientific outlooks can acquire a general cultural, worldview sense only if they are visualized, which ensures their understanding not only by specialists in this field of knowledge but also by researchers specializing in other sciences and even educated people who are not directly involved in scientific activity. 
In itself, the scientific worldview cannot be stable in terms of content and structure. It has been constantly evolving. As already noted, Ukrainian scientists pay particular attention to the economic worldview. For modern economic knowledge, it is necessary to understand that the orientation to insatiable consumption leads the world along a deadly path. And the expectations of some researchers of new social patterns for a "market signal" about the need to abandon this orientation appear to be false.

According to prominent Western scholars, the purpose of markets is to be effective, not sufficient; profit-seeking, not fair. Markets have never set themselves the goal of achieving solidarity or integrity, beauty or justice, sustainability or spirituality. They are not intended for this... Markets, if allowed to work normally, achieve their goals very well, but these goals are far from the general purpose of a person. To achieve the highest goal, mechanisms of politics, culture, religion are used. And, if someone admits the idea that these greatest achievements of the human spirit can be replaced by economic theories, we are at risk of trampling on our souls [5].

The analysis of the literature sources $[5 ; 7 ; 8 ; 23 ; 24$ and others] has allowed to define:

- the concept of theoretical economic worldview as a system of scientifically based subjective social ideas of implementing sound economic activity;

- the concept of practical economic worldview as an empirically determined set of subjective social ideas of implementing economic activity based on traditional principles;

- the concept of scientific economic worldview as an ordered in a certain way set of subjective social ideas of implementing economic activity.

It is of no doubt that both a practicing economist and a scientist should have the ability to make philosophical worldview generalizations about the current relationship between nature and society, the need to preserve humanity, its transfer to a new model of civilizational development. But for an economist, a deep understanding of human survival is especially important. Indeed, the uncontrolled growth of industrial production is the first fundamental factor in the destruction of the biosphere due to a rapid increase in the consumption of energy and clean fresh water, a decrease in the area of forest plantations, as well as an increase in the amount of harmful waste.

Mastering the scientific economic worldview, according to V. Volovich, will allow studying objective economic reality with all its contradictions. "To a certain extent, the scientific economic worldview is called upon to cognize (reflect) objective economic laws. On the other hand, the scientific economic worldview can be used in forming the economic policy of a particular state. There is a peculiar pluralism of economic outlooks and doctrines at any stage in the development of human society. The latter goes to prove that no school of economic thought historically disappears without a trace" [8].

In studying worldview special attention should be paid to factors contributing to its change. These include qualitative changes in people's lives (revolutions, reforms, wars, etc.); changes in family relationships; significant changes in the immediate social environment (friends, colleagues, managers); changes in the quality of a person's life; the content of social institutions aimed at ensuring progressive trends in changes in the worldview of members of society. The economic worldviews of a Ukrainian are influenced by the following factors: transformation of Ukrainian society; globalization and formation of a new world order; growth in the level of worldview freedom and spiritual quest of an individual.

In managing the formation of a worldview, it is necessary, first of all, to make its implicit contradictions explicit, to present their boundaries and put a person who needs to change his/her worldview in a situation where he/she needs to make a choice. Here, in order for a person to make a worldview choice corresponding to reality, it is important to present arguments both against other worldviews (so that the person could understand their limitations) and in support of a progressive worldview concept.

It makes sense to use positive trends in the evolution of management to develop a paradigm for controlling the development of a person's worldview. The fundamental principle of this paradigm is that in relation to the worldview management should not be considered as the art of controlling people but as the art of creating unique conditions for a more efficient use of internal conscious sources to implement creative ideas of individuals who demonstrate high intellectual activity and have specific knowledge.

Solving the problems of the worldview of society can be facilitated by updating the concepts of the educational sphere. On this occasion, S. Beketova and the co-authors note: "The difficult socio-economic situation has caused searching for new worldviews for the young generation and determined the main goal of education - teaching a person to treat the outside world from the standpoint of modern science, clearly define his/her attitude to reality, understand the meaning of what is happening, form the ability for independent judgment. Worldview knowledge, attitudes, beliefs, evaluative skills formed in the educational process are interpreted, processed and converted into values that determine the position of students in relation to the surrounding reality" [3]. A person with naive, unenlightened consciousness does not have sufficient means for a clear, consistent, rational justification of his/her views, often turning to fantastic fiction, crafts, and customs.

Our worldview largely depends on the most important component of education - upbringing. The fact is that until now the result of education is considered to be knowledge. But, unfortunately, our knowledge is mainly aimed at finding ways to use resources to meet human needs and not at all for the joint harmonious development of the human community. Overcoming these discrepancies in the process of developing the sphere of upbringing and education will solve many problems of the formation of a humanistic worldview and, on this basis, the productive social consolidation. S. Myakinnikov gives the following explanation of this process: "Worldview knowledge allows producing special forms of spiritual exploration of reality and an individual's perceiving him/ herself as an existing and cognizing one. It turns out to be a support for identifying the value of the cognized objects of reality and activities as well as for determining his/her own place and the role of the latter in society and nature ... On the one hand, the worldview directs a person perceiving life values to cognition and practical mastering of the phenomena of the world; on the other hand, it itself is a value for its bearer and, possibly, other individuals, which is acquired in the course of socialization of the person" [17].

Resources should be directed at both practical and theoretical knowledge. It is knowledge that has acquired the role of the main production resource determining social life over the past century. As a consequence, education became an essential social value; the principles of meritocracy were formed; a new class, which can be called the "class of knowledge producers" or the "class of intellectuals", emerged. 
The processes of consolidation and solidarity are being implemented in the scientific sphere of society as well. They are clearly manifested in schools of thought. These are small informal creative groups that formulate, assume and promote relevant paradigms. The most talented scientists belong either simultaneously or sequentially to several groups of this type. A school of thought implements the following functions: producing scientific knowledge; disseminating knowledge; training qualified scientists. It is generally accepted that the life cycle of a scientific school comprises three generations: the founder of the school; his/her followers; disciples of the followers.

The leader of a school of thought has a degree of Doctor of Sciences (Professor). The school should have three doctors of sciences in one specialty. It differs from the usual scientific team in a number of ways:

1) the research topics of a scientific school are more uniform than those of a laboratory or department;

2) a school of thought informally divides scientists into idea men, critics, erudites, etc.;

3 ) in a school of thought, the leader of the younger generation is a representative of this school.

Changes in the worldview should be associated with the humanization of man and humanity. Presently, national ideologies and strategies for the successful development of society are built on this worldview foundation.

Conclusions. In general, the following conclusions can be drawn from the above materials. Life activities of the members of a society and the degree of their consolidation depend on their world outlook. In Ukraine, mechanisms for a deliberate streamlining of socio-economic processes, diagnosing of reserves for the development of worldview do not yet work. The study of this concept will allow organizing a dialogue between people with different worldviews and, on this basis, specifying a constructive social pattern. Solving complex tasks set by the internal development of our society and the international situation is possible due to the formation of a systematic scientific worldview. To provide a solution to the problems of the worldview of society, it is necessary to update the concepts of the educational sphere. Technologies and programs for the development of knowledge are concentrating more on finding effective ways to use resources for meeting human needs, less - on improving relationships, the joint harmonious development of the human community. Overcoming these discrepancies in the process of developing the sphere of upbringing and education will solve many problems related to the formation of a humanistic worldview and, on this basis, the productive social consolidation. In managing a worldview, it is necessary to focus on enhancing internal conscious sources of people's desire to carry out their own unique ideas in practice. The processes of consolidation and solidarity are implemented both in society and in the scientific sphere of society. They are clearly manifested in schools of thought that implement the following functions: producing scientific knowledge; disseminating knowledge; training qualified scientists.

\section{LITERATURE}

1. Андрущенко В. Світоглядна навігація освіти: як вивчення філософії формує духовно спроможну особистість // Україна молода. 21.03.2018. URL: https://umoloda.kyiv.ua/ number/3289/188/121660/
2. Асеев А. Л. Без науки у России нет будущего. ЭКО. 2010. T. 1. № 1. С. 1-18.

3. Бекетова С. И., Садретдинов Д. Ф., Гайсин Р. И. Диагностика сформированности научного мировоззрения школьников V1-1X классов в процессе обучения географии. Филология и культура. 2013. № 1. С. 231-235.

4. Большаков Е. В., Федотов Е. В. Мировоззрение и его роль в формировании морального и правового сознания личности. Среднерусский вестник общественных наук. 2013. № 2. C. 7-10.

5. Вайцзеккер Э., Ловинс Э., Ловинс Л. Фактор четыре. Затрат - половина, отдача - двойная. Новый доклад Римскому клубу. М. : Academia, 2000. 400 c.

6. Ватулин А. И. Идеология и её механизмы // Хрестоматия к учебнику по политической психологии : учеб. пособие. СПб. : Коло, 2012. 296 с.

7. Вернадский В. И. О научном мировоззрении // На переломе. Философские дискуссии 20-х годов. Философия и мировоззрение. М., 1990. С. 180-203.

8. Волович В. Н. Роль экономического мировоззрения в развитии человеческого общества. Записки Горного инстиmyma. 2005. T. 163. C. 223-226.

9. Гофман А. Б. Солидарность или правила, Дюркгейм иди Хайек? О двух формах социальной интеграции // Социологический ежегодник 2012. М. : ИНИОН РАН ; Кафедра общей социологии НИУ ВШЭ, 2013. С. 97-167.

10. Жилин В. И. К вопросу о механизмах формирования синергетического мировоззрения. Философия и общество. 2011. № 4. C. 87-96.

11. Зеленков А. И. Устойчивое развитие и социальноэкологические параметры качества жизни. Минск, 2011. 292 c.

12. Зеленов Л. А., Владимиров А. А. Матрица общей теории мировоззрения // Мировоззренческая парадигма в философии: Основоположения онтогносеологии : колл. моногр. Нижний Новгород : ННГАСУ, 2018. 269 с.

13. Зуев К. А., Кротков Е. А. Мировоззрение, философия, наука: проблема их соотношения и взаимодействия. Гуманитарные науки. 2013. № 3. С. 4-10.

14. Идеология и философия солидаризма : материалы научного семинара. М. : Научный эксперт, 2010. Вып. № 9. 128 с.

15. Ильин В. В., Машенцев А. В. Философия в схемах и комментариях : учеб. пособие. СПб. : Питер, 2005. 304 с.

16. Мировоззренческая парадигма в философии: Основоположения онтогносеологии : колл. монография / рук. авт. колл. и отв. ред. - проф. М. М. Прохоров. Нижний Новгород : ННГАСУ, 2018. 269 c.

17. Мякинников С. П. Основные аспекты архитектоники мировоззрения как социального феномена. Вестник Челябинского государственного университета. Серия «Философия. Социология. Культурология». 2013. № 33. Вып. 30. С. 7-15.

18. Надольний І. Ф. Світоглядна парадигма - теоретична основа економічної трансформації суспільства // Бізнесаналітика в управлінні зовнішньоекономічною діяльністю : матеріали V Міжнар. наук.-практ. конф. Київ, 2018. С. 131-133.

19. Окара А. Н. Социальная солидарность как основа нового «миростроительного» проекта // Идеология и философия солидаризма : материалы научного семинара. М. : Научный эксперт, 2010. Вып. № 9. С. 7-42.

20. Солидарность и конфликты в современном обществе // Материалы научной конференции «XII Ковалевские чтения» (15-17 ноября 2018 г.). СПб. : Скифия-принт, 2018. 600 с.

21. Степин В. С. Научное познание и ценности техногенной цивилизации. Вопросы философии. 1989. № 10. С. 3-18. 
22. Україна 2030: Доктрина збалансованого розвитку. Львів : Кальварія, 2017. 164 с. URL: http://econom.chnu.edu.ua/ wp-content/uploads/2018/03/E-Book-Doctrine-2030.pdf

23. Филипенко А. С. Народная, солидарная экономика: концептуальный эскиз. Экономика Украины. 2016. № 6. C. 19-28.

24. Ціннісні орієнтири інституціоналізації економічного розвитку : кол. моногр. / за заг. ред. А. О. Задої. Дніпропетровськ, 2010. 768 c.

25. Швейцер А. Культура и этика. М. : Прогресс, 1973. 337 c.

26. Шрейбер В. К. Наука. Философия. Мировоззрение // Мировоззренческая парадигма в философии: Основоположения онтогносеологии : колл. монография. Нижний Новгород : ННГАСУ, 2018. С. 149-162.

27. Ярмол Л. В. Співвідношення понять світогляду та поглядів людини: теоретико-правові аспекти. Вісник Національного університету «Львівська політехніка». Юридичні науки. 2016. № 837. C. 383-389.

\section{REFERENCES}

Andrushchenko, V. "Svitohliadna navihatsiia osvity: yak vyvchennia filosofii formuie dukhovno spromozhnu osobystist" [Worldview Navigation of Education: How the Study of Philosophy Forms a Spiritually Able Person]. Ukraina moloda. 21.03.2018. https://umoloda.kyiv.ua/number/3289/188/121660/

Aseyev, A. L. "Bez nauki u Rossii net budushchego" [Without Science, Russia Has no Future]. EKO, vol. 1, no. 1 (2010): 1-18.

Beketova, S. I., Sadretdinov, D. F., and Gaysin, R. I. "Diagnostika sformirovannosti nauchnogo mirovozzreniya shkolnikov VI-IX klassov v protsesse obucheniya geografii" [Diagnostics of the Formation of the Scientific Worldview of Students of Grades $\mathrm{VI}-\mathrm{IX}$ in the Process of Teaching Geography]. Filologiya i kultura, no. 1 (2013): 231-235

Bolshakov, Ye. V., and Fedotov, Ye. V. "Mirovozzreniye i yego rol $v$ formirovanii moralnogo i pravovogo soznaniya lichnosti" [Worldview and its Role in the Formation of Moral and Legal Consciousness of the Individual]. Srednerusskiy vestnik obshchestvennykh nauk, no. 2 (2013): 7-10.

Filipenko, A.S. "Narodnaya, solidarnaya ekonomika: kontseptualnyy eskiz" [People, Solidarity Economy: Conceptual Sketch]. Ekonomika Ukrainy, no. 6 (2016): 19-28.

Gofman, A. B. "Solidarnost ili pravila, Dyurkgeym ili Khayek? O dvukh formakh sotsialnoy integratsii" [Solidarity or Rules, Durkheim or Hayek? About Two Forms of Social Integration]. In Sotsiologicheskiy yezhegodnik 2012, 97-167. Moscow: INION RAN; Kafedra obshchey sotsiologii NIU VShE, 2013.

Ideologiya i filosofiya solidarizma: materialy nauchnogo seminara [The Ideology and Philosophy of Solidarity: Materials of a Scientific Seminar], issue 9. Moscow: Nauchnyy ekspert, 2010.

Ilin, V. V., and Mashentsev, A. V. Filosofiya v skhemakh i kommentariyakh [Philosophy in Diagrams and Comments]. St. Petersburg: Piter, 2005.

Mirovozzrencheskaya paradigma $v$ filosofii: Osnovopolozheniya ontognoseologii [The Worldview Paradigm in Philosophy: the Foundations of Ontognoseology]. Nizhniy Novgorod: NNGASU, 2018.

Myakinnikov, S. P. "Osnovnyye aspekty arkhitektoniki mirovozzreniya kak sotsialnogo fenomena" [The Main Aspects of the Architectonics of Worldview as a Social Phenomenon]. Vestnik Chelyabinskogo gosudarstvennogo universiteta. Seriya «Filosofiya. Sotsiologiya. Kulturologiya», vol. 33 (2013): 7-15.

Nadolnyi, I. F."Svitohliadna paradyhma - teoretychna osnova ekonomichnoi transformatsii suspilstva" [The Worldview Paradigm is the Theoretical Basis of Economic Transformation of Society]. Biznes-analityka $v$ upravlinni zovnishnyoekonomichnoiu diialnistiu. Kyiv, 2018. 131-133.

Okara, A. N. "Sotsialnaya solidarnost kak osnova novogo "mirostroitelnogo» proekta" [Social Solidarity as the Basis of a New "Peace-building" Project]. Ideologiya i filosofiya solidarizma, issue 9. Moscow: Nauchnyy ekspert, 2010. 7-42.

"Solidarnost i konflikty v sovremennom obshchestve" [Solidarity and Conflicts in Modern Society].XII Kovalevskiye chteniya. St. Petersburg: Skifiya-print, 2018.

Shreyber, V. K. "Nauka. Filosofiya. Mirovozzreniye" [The Science. Philosophy. Worldview]. In Mirovozzrencheskaya paradigma $v$ filosofi: Osnovopolozheniya ontognoseologii, 149-162. Nizhniy Novgorod: NNGASU, 2018.

Shveytser, A. Kultura i etika [Culture and Ethics]. Moscow: Progress, 1973.

Stepin, V. S. "Nauchnoye poznaniye i tsennosti tekhnogennoy tsivilizatsii" [Scientific Knowledge and Values of Technogenic Civilization]. Voprosy filosofii, no. 10 (1989): 3-18.

Tsinnisni oriientyry instytutsionalizatsii ekonomichnoho rozvytku [Values of Institutionalization of Economic Development]. Dnipropetrovsk, 2010.

"Ukraina 2030: Doktryna zbalansovanoho rozvytku" [Ukraine 2030: The Doctrine of Balanced Development]. Lviv : Kalvariia, 2017. http://econom.chnu.edu.ua/wp-content/uploads/2018/03/ E-Book-Doctrine-2030.pdf

Vatulin, A. I. "Ideologiya i yee mekhanizmy" [Ideology and its Mechanisms]. In Khrestomatiya kuchebniku po politicheskoy psikhologii. St. Petersburg: Kolo, 2012.

Vaytszekker, E., Lovins, E., and Lovins, L. Faktor chetyre. Zatrat - polovina, otdacha - dvoynaya. Novyy doklad Rimskomu klubu [Factor four. The Cost is half, the Return is double. New Report to the Club of Rome]. Moscow: Academia, 2000.

Vernadskiy, V. I. "O nauchnom mirovozzrenii" [On the Scientific Worldview]. In Na perelome. Filosofskiye diskussii 20-kh godov. Filosofiya i mirovozzreniye, 180-203. Moscow, 1990.

Volovich, V. N. "Rol ekonomicheskogo mirovozzreniya v razvitii chelovecheskogo obshchestva" [The Role of the Economic Worldview in the Development of Human Society]. Zapiski Gornogo instituta, vol. 163 (2005): 223-226.

Yarmol, L. V. "Spivvidnoshennia poniat svitohliadu ta pohliadiv liudyny: teoretyko-pravovi aspekty" [The Relation between the Concepts of Worldview and Views of Man: Theoretical and Legal Aspects]. Visnyk Natsionalnoho universytetu «Lvivska politekhnika». Yurydychni nauky, no. 837 (2016): 383-389.

Zelenkov, A. I. Ustoychivoye razvitiye i sotsialno-ekologicheskiye parametry kachestva zhizni [Sustainable Development and Socio-environmental Parameters of Quality of Life]. Minsk, 2011.

Zelenov, L. A., and Vladimirov, A. A. "Matritsa obshchey teorii mirovozzreniya" [The Matrix of the General Theory of Worldview]. In Mirovozzrencheskaya paradigma v filosofii: Osnovopolozheniya ontognoseologii. Nizhniy Novgorod: NNGASU, 2018.

Zhilin, V. I. "K voprosu o mekhanizmakh formirovaniya sinergeticheskogo mirovozzreniya" [To the Question of the Mechanisms of Formation of a Synergetic Worldview]. Filosofiya i obshchestvo, no. 4 (2011): 87-96.

Zuyev, K. A., and Krotkov, Ye. A. "Mirovozzreniye, filosofiya, nauka: problema ikh sootnosheniya i vzaimodeystviya" [Worldview, Philosophy, Science: the Problem of Their Relationship and Interaction]. Gumanitarnyye nauki, no. 3 (2013): 4-10.

Стаття надійшла до редакції 08.11.2019 p. 